\title{
Leadership and Work Environment: The Impact on the Performance of MSME Employees in Tegal City
}

\author{
Setyowati Subroto, Mei Rani Amalia* \\ Management Study Program, Universitas Pancasakti Tegal, Indonesia \\ *Corresponding author email: meiraniamalia20@gmail.com
}

\begin{abstract}
MSMEs in Indonesia have a very important role, we can said that they are the backbone of the Indonesian economy. Based on BPS data, about 99\% of existing business units are MSMEs, which able to absorb about $96.3 \%$ of the workforce from the number of productive workers available. In order to maintain and grow up their business, MSME owners need to have a strong leadership spirit in guiding their employees so as to produce positive performance. A decent work environment should also be considered so that MSME employees will feel comfortable workplace which can ultimately achieve the expected performance. But in fact, many employees sometimes were not got attention from their owner. Then, work environment were not comfortable to work. The study was conducted to prove the influence of leadership and work environment on the performance of MSME employees in Tegal City. Samples was obtained from purposive sampling method and data was collected through observations, interviews, and questionnaires. Data analysis method used multiple linear regression analysis. The result proved that significantly, leadership and work environment had influence on the performance of MSME employees in Tegal City, both partially and simultaneously.
\end{abstract}

\section{Keywords: MSME, Leadership, Work Environment, Performance}

\section{INTRODUCTION}

MSMEs are small scale economic actors, in other side they gave great contribution to economic sector in Indonesia, they could defend while the economic was in bad condition and many big industries went to bankcrupt [1]. Indonesia had a lot of business unit in the whole economic sectors which contributed to national income or job opportunities. MSMEs also had great role in order to spread national economy [2]. Not only Indonesia, MSMEs in many countries of the world drived the economy, they were very responsive to the government policies in boosting export-oriented economic growth. MSMEs growth and development were considered crucial to increase aggregate expenditure and job opportunities [2].

Essentially, the entrepreneurship spirit of Indonesian people, especially in Tegal city were quite high. This was seen from the number of built MSMEs 930 units from 1.940 units recorded in Dinas Koperasi, Perdagangan, dan UMKM Kota Tegal [3].
However, there were some problems faced by MSMEs, an example was many businesses those go out after while opened. This problem showed that leadership in MSMEs had a crucial role. Leadership in MSMEs had a way to adapt, both in the work process and in its development strategy [4] . A leader also had an important role in various functions in the organization, especially to survive and maintain their entities in business competition[5] . The organization could operate well if there were a positive bond between employees and the leader. Therefore, the role of the leader becomes very strategic in determining employee performance and overall organization goals. Another problem faced by MSME employees in Tegal city was a less comfortable and conducive work environment, whereas a pleasant work environment will provide satisfaction and can motivate employees to work optimally so that organizational performance will improve[6]. Beside to humans, the work environment was an important factor in achieving optimal performance. So that, the work environment must still be considered because the organization's 
goals cannot be achieved if the work environment was not conducive.

Based on the background of the problems, this research was carried out to find out the impact of leadership and the work environment on the performance of MSME employees in Tegal City.

\section{LITERATURE REVIEWS}

\subsection{Micro, Small, and Medium Entreprises (MSMEs)}

MSMEs are the efforts carried out by the community and the results are used for the community itself [2]. They build a business using their own capital or borrow from other individuals to meet their needs or the needs of other individuals who benefit from their business. They build businesses using their own capital or borrow from other parties to meet their needs and other person's need who got benefit from their business.

The development of MSMEs is not only the responsibility of the government, but this must be positive cooperation between the government, the private sector, and the public [2]. MSMEs also do not only rely on help from other parties, but they must have independent strength to be able to maintain and develop their business.

\subsection{Leadership}

Leadership is the process between relationships between employees, superiors under certain conditions [7]. In other opinion, 1 eadership is the process of giving influence to the activities of people or groups to realize goals in a situation [8]. Leadership is the process of giving influence to the activities of people or groups to realize goals in a situation. The element of leadership consists of:

\subsubsection{A group of individuals}

In an organization there is a group of individuals who are working to achieve organizational purposes. Members of the organization will get orders or directions through superiors.

\subsubsection{Power;}

Superiors have the authority to direct and organize their members to perform tasks.

\subsubsection{Affects;}

Superiors use their power in giving influence to members to be willing to perform tasks.

2.2.4. Values;

The potential to use the previous three elements and recognize if the potential is related to the value [9].

\subsection{Work Environment}

A conducive work environment will give comfortness for employees to work. Work environment is all of thing around the employee and it gives influences while they are working, such as musics, lighting, cleaness, and so on[10].Then, there are factors giving influences for creating a work environment related to employees potential:

\subsubsection{Lighting}

Lighting has important role to create work safety and smoothness, so the management should give attention to ensure the work environment has a good light.

\subsubsection{Temperature at work place}

At the normal conditions, the body has an unequal temperature. A person's body is always trying to maintain normal conditions, so it will able to adapt to outside conditions.

\subsubsection{Humidity at work place}

Humidity is the amount of water in the air, it expressed by percentage. Humidity is related to air temperature and simultaneously between humidity, temperature, the speed of moving air can affect the condition of the human body when releasing or receiving heat from the body.

\subsubsection{Air circulation at work place}

The existence of $\mathrm{O} 2$ around the workplace and also the psychological influence due to the presence of plants around the work site, both of which will provide freshness and coolness to the body.

\subsubsection{Noising at work place}

Employees need focused, a noise should be anticipated so that all employees could do working efficiently, and finally achieve great productivities.

\subsubsection{Mechanical vibration at work place}

Mechanical vibration which is felt by employee will give unwanted things.

\subsubsection{Smelling at work place}

The existence of smells at work place could be said as a pollution, because it influences work focussed. A continuously smell will affect the sensitivity of smelling.

\subsubsection{Colour at work place}

Colour design could be separated by facilities layout, because colour has strong influence to the feeling [11]

\subsubsection{Decoration at work place}

Decoration is related to good colour arrangement, it will motivate employees to work. 


\subsubsection{Music at work place}

Music that is melodiously aligned at the location, time, atmosphere can stimulate or excite employees to work.

\subsubsection{Security at work place}

Safety factors in the workplace are essential to ensure employees can work safely [11].

\subsection{Performance}

Performance defined by the result of a planned work process in the place and time of the employees and related organizations [12].

Performance is affected by the following factors :

\subsubsection{Personal factors;}

It includes elements of skills, insight, confidence, ability, commitment, motivation that belongs to each employee.

\subsubsection{Leadership factors;}

It is Covering aspects of the quality of team leaders and managers to provide motivation, morale, support, work direction for employees.

\subsubsection{Team factors;}

It consists the quality of spirit and support provided by friends in one organization, trust among members of the organization, the cohesiveness and cohesiveness of the organization.

\subsubsection{System factors;}

It could be work facilities, work systems in the organization, performance culture or organizational processes in the organization.

\subsubsection{Contextual factors;}

It covers a change and environmental pressures inside or outside [12].

\section{METHOD}

This study used quantitative analysis methods. The population in the study was Tegal city MSME employees. Sampling techniques used by research were non-probability sampling, purposive sampling method, which was samples taken based on a criterion. The criteria of this sample are employees of food or beverage MSMEs who already have P-IRT certificates and or HALAL MUI certificates, under the auspices of related agencies, and have active instagram social media.

The validity test was conducted to determine the question on the questionnaire to be used in the study valid or not by seeing the differences of $r$ count and $r$ table values. If $r$ count $>r$ table questions were considered valid, while if $r$ count $<r$ table questions were not valid.

Realibility testing was conducted to find out if the questionnaire to be used in the study proved consistency to know symptoms that were no different. The criteria was when a Cronbach Alfa value > 0.60 statement was considered reliable, and conversely if a Cronbach Alfa $<0.60$, the statement was considered non-reliable [13].

Data analysis methods use multiple regressions, which correspond to exposure [14]. Multiple regressions were used to perform tests on one independent variable. Multiple regression equations are:

$$
\mathrm{Y}=\mathrm{a}+\mathrm{b}_{1} \mathrm{X}_{1}+\mathrm{b}_{2} \mathrm{X}_{2}+\mathrm{e}
$$

Note: $\mathrm{Y}=$ Performance

$$
\begin{aligned}
\mathrm{a} & =\text { constant } \\
\mathrm{b} & =\text { beta coefficient } \\
\mathrm{X}_{1} & =\text { leadership } \\
\mathrm{X}_{2} & =\text { work environment } \\
\mathrm{e} & =\text { error term }
\end{aligned}
$$

\section{FINDING AND DISCUSSION}

\subsection{Instrument Testing}

In the validity test, it was known that the magnitude of the $r$ table at a significance level of 5\% was 0.25 . Results of validity test $\mathrm{X} 1, \mathrm{X} 2$, and $\mathrm{Y}$ in the study were:

Table 2. Validity Test Results

\begin{tabular}{c|c|c|c}
\hline $\begin{array}{c}\text { Indicator } \\
\mathrm{s}\end{array}$ & $\begin{array}{c}\text { Correlatio } \\
\mathrm{n}\end{array}$ & $\begin{array}{c}\text { Significanc } \\
\mathrm{e}\end{array}$ & $\begin{array}{c}\text { Informatio } \\
\mathrm{n}\end{array}$ \\
\hline $\mathbf{X}_{1.1}$ & 0,654 & 0,000 & Valid \\
$\mathbf{X}_{1.2}$ & 0,394 & 0,000 & Valid \\
$\mathbf{X}_{1.3}$ & 0,913 & 0,000 & Valid \\
$\mathbf{X}_{1.4}$ & 0,936 & 0,000 & Valid \\
$\mathbf{X}_{1.5}$ & 0,654 & 0,000 & Valid \\
$\mathbf{X}_{1.6}$ & 0,936 & 0,000 & Valid \\
\hline $\mathbf{X}_{2.1}$ & 0,922 & 0,000 & Valid \\
$\mathbf{X}_{2.2}$ & 0,922 & 0,000 & Valid \\
$\mathbf{X}_{2.3}$ & 0,923 & 0,000 & Valid \\
$\mathbf{X}_{2.4}$ & 0,313 & 0,015 & Valid \\
$\mathbf{X}_{2.5}$ & 0,922 & 0,000 & Valid \\
$\mathbf{X}_{2.6}$ & 0,541 & 0,000 & Valid \\
$\mathbf{X}_{2.7}$ & 0,266 & 0,040 & Valid \\
$\mathbf{X}_{2.8}$ & 0,764 & 0,000 & Valid \\
\hline $\mathbf{Y}_{1}$ & 0,904 & 0,000 & Valid \\
$\mathbf{Y}_{\mathbf{2}}$ & 0,904 & 0,000 & Valid \\
$\mathbf{Y}_{\mathbf{3}}$ & 0,904 & 0,000 & Valid \\
$\mathbf{Y}_{\mathbf{4}}$ & 0,657 & 0,000 & Valid \\
$\mathbf{Y}_{\mathbf{5}}$ & 0,793 & 0,000 & Valid \\
$\mathbf{Y}_{\mathbf{6}}$ & 0,915 & 0,000 & Valid \\
\hline Processed SPSS Data & \multicolumn{2}{|l}{}
\end{tabular}

The results of the $\mathrm{X} 1, \mathrm{X} 2, \mathrm{Y}$ variable reliability tests in the study were: 
Table 3. Reliability Test Results

\begin{tabular}{c|c|c}
\hline Variables & $\begin{array}{c}\text { Alpha } \\
\text { Cronbach }\end{array}$ & Information \\
\hline $\mathrm{X}_{1}$ & 0,764 & Reliable \\
$\mathrm{X}_{2}$ & 0,793 & Reliable \\
$\mathrm{Y}$ & 0,774 & Reliable \\
\hline
\end{tabular}

\subsection{Data Analysis Result}

Results of calculation of data analysis between leadership, the work environment on employee performance were obtained:

Table 4. Test Result of Regression

\begin{tabular}{|c|c|c|c|c|c|}
\hline \multicolumn{6}{|c|}{ Coefficients ${ }^{n}$} \\
\hline & Unstandardize & Coefficients & $\begin{array}{l}\text { Standardized } \\
\text { Coefficients }\end{array}$ & $\mathrm{T}$ & Sig. \\
\hline $\begin{array}{l}\text { Model } \\
1 \quad \text { (Constant) }\end{array}$ & $\begin{array}{l}\text { B } \\
-24,052\end{array}$ & $\begin{array}{l}\text { Std. Error } \\
5,260\end{array}$ & Beta & $-4,572$ &, 000 \\
\hline $\mathrm{X} 1$ & 1,824 & ,318 & ,534 & 5,744 &, 000 \\
\hline $\mathrm{X} 2$ & 1,187 & ,267 &, 413 & 4,438 &, 000 \\
\hline
\end{tabular}

Based on table 4 above, the regression equation is: $\mathrm{Y}=-24,052+1,824(\mathrm{X} 1)+1,187(\mathrm{X} 2)+\mathrm{e}$. This means that 1) the constant of $-24,052$ means that if the leadership variable and work environment are considered constant at 0 , employee performance (Y) was reduced to $-24,052 ; 2) \mathrm{X} 1=1,824$ means that if leadership ran well, employee performance (Y) will improve; 3) $\mathrm{X} 2=1,187$, means that if the work environment is pleasant, comfortable, will result in an improvement in performance (Y) employees assume other independent variables were considered constant.

Individual tests use the test, which was used to see if leadership had an effect on employee performance and to see if the work environment had an impact on employee achievement. Based on table 4 , the calculated value of 5.744 has a value of 0.000 , the significance value below alpha $(\alpha) 0.05$; This had proven that there wass a leadership influence on employee performance. While the calculated value of 4.438 has a significance value of 0.000 , the significance value is below alpha $(\alpha) 0.05$; This has proven that there was an influence of the work environment on employee performance.
Table 5. Test Result

\section{ANOVA $^{\mathrm{b}}$}

\begin{tabular}{lrrrrr}
\hline & Sum of & Mean & & \\
Model & Squares & Df & Square & $\mathrm{F}$ & Sig. \\
1 Regressio & 1719,01 & 2 & 859,50 & 106,05 &, 000 \\
$\mathrm{n}$ & 7 & & 8 & 1 & $\mathrm{~b}$ \\
Residual & 461,967 & 5 & 8,105 & & \\
& & 7 & & & \\
Total & 2180,98 & 5 & & & \\
\multicolumn{4}{r}{} \\
\hline
\end{tabular}

a. Predictors: (Constant), Leadershp, Work

Environment

b. Dependent Variable: kinerja

Source : Output of SPSS 19 (2021)

Testing simultaneously used $\mathrm{F}$ testing, which $\mathrm{F}$ testing used to see if leadership and the work environment had an impact on employee performance. Based on table 5 above, the value $\mathrm{F}$ of 106.051 has a value of 0.000 which was below alpha $(\alpha)$ 0.005; Then it proved there was an effect of leadership and work environment on employee performance.

Table 6. Calculation of Coefficient of Determination $\left(\mathrm{R}^{2}\right)$

\begin{tabular}{lllll}
\hline & & & & \\
& & & AdjustedR & Std.Error of the \\
Mdl & $\mathrm{R}$ & RSquare & Square & Estimate \\
1 &, $888^{\mathrm{a}}$ &, 788 &, 781 & 2,84687 \\
& & & & \\
\hline a. & Predictors: (Constant), leadership, work environment
\end{tabular}

a. Predictors: (Constant), leadership, work environment

Determination was used to see how much the variables of the work environment and leadership simultaneously affect employees' perform. Table 6 proved the R-Square value/ coefficient of determination of 0.781 ; This had proven that the high impact of work environment and also leadership on employee achieving was $78.1 \%$, while $21.9 \%$ is given the influence of variables which was not discussed in the study.

\subsection{Discussion}

\subsubsection{Leadership Influenced on Employee Performances}

The result of the study proved, good leader had a high influence on employees work. In addition, leaders can involve employees in decision making, coud provide good transparency to employees and leaders have to motivate employees to carry out innovations to work. The results of the study proved that good leadership can also have a positive influence on employee performances [15]. 


\subsubsection{Work Environment Influenced on Employees Performance}

The results of the study proved that a pleasant, comfortable work environment could improve employees performance. A comfortable and safe work environment makes employees more actively work to increase performance [16]. In addition, good bonding between leaders and employees is also a factor that must be considered and prioritized to create a positive work environment [17].

\subsubsection{The Impact of Leadership and the Work Environment on MSMEs Employees Performance}

The result showed that the value of $\mathrm{F}$ of 106.051 has a significance value of 0.000 which means that the work environment and leadership affect employee performance. Shows if the 3rd hypothesis that states the influence of leadership and the work environment on employee performance is not rejected. Employee performance can be maintained by paying attention to work environment and leadership factors [18].

\section{CONCLUSION}

Based on the results of research and discussion, it can be said that simultaneously independent variables in the study, namely leadership and work environment, had a significant positive influence on employee performance as variables depending on $78.1 \%$, while $21.2 \%$ are influenced by other factors outside the variables studied. Partially, the leadership variable had a significant positive effect of $53.4 \%$. The work environment variable had significantly positive effect of $41.3 \%$.

\section{REFERENCES}

[1] Suseno Yd, Suddin A. Analisis Pengaruh Achievment, Inovasi Terhadap Kinerja Entrepreneur UKM Pengrajin Home Industri Batik Dengan Personal Control Sebagai Variabel Moderating Di Surakarta. Research Fair Unisri. 2019 Jan;3(2019):579-606.

[2] Qomariah N. Pengaruh Program Kemitraan, Lingkungan Kerja Dan Motivasi Terhadap Kinerja Karyawan UMKM Di Kecamatan Bangil. Jurnal Riset Ekonomi Dan Manajemen. 2016 May 19;16(1).

[3] Fathurrohman. Selamatkan Umkm Kota Tegal. Www.Fin.Co.Id. 2020.
[4] Kocherbaeva A, Samaibekova Z, Isabaeva K. Leadership And Leaders In Successful Small And Medium Enterprises. In: Proceedings Of The 4th International Conference On Social, Business, And Academic Leadership (Icsbal 2019). Paris, France: Atlantis Press; 2019.

[5] Madanchian M, Taherdoost H. Role Of Leadership In Small And Medium Enterprises (Smes) [Internet]. Available From: Http://Www.Ahooraltd.Comhttp://Www.Hamt a.Org

[6] Andari. Pengaruh Kepemimpinan Dan Lingkungan Kerja Terhadap Kinerja Pegawai Dinas Koperasi Dan Umkm Provinsi Banten. Jurnal Sains Manajemen. 2016 Jun;2(2016):1626.

[7] Muhammad Busro. Teori-Teori Manajemen Sumber Daya Manusia. Jakarta: Prenadamedia Group; 2017.

[8] Indriyo Gitosudarmo, I Nyoman Sudita. Perilaku Keorganisasian. Yogyakarta: Bpfe; 1997.

[9] Bangun W. Manajemen Sumber Daya Manusia. Jakarta: Erlangga; 2012.

[10] Danang Sunyoto. Teori, Kuesioner Dan Analisis Data Sumber Daya Manusia (Praktik Penelitian). Yogyakarta: Center For Academic Publishing Service (Caps).; 2012.

[11] Sedarmayanti. Tata Kerja Dan Produktivitas Kerja: Suatu Tinjauan Dari Aspek Ergonomi Atau Kaitan Antara Manusia Dengan Lingkungan Kerjanya. Bandung: Mandar Maju; 2011.

[12] Sjafri Mangkuprawira, Aida Vitayala Hubeis. Manajemen Mutu Sumber Daya Manusia. Bogor: Ghalia Indonesia; 2007.

[13] Uma Sekaran. Research Methods For Business. Jakarta: Penerbit Salemba Empat; 2007.

[14] Imam Ghozali. Desain Penelitian Kuantitatif Dan Kualitatif Untuk Akuntansi, Bisnis Dan Ilmu Sosial Lainnya. Semarang: Yoga Pratama; 2016. 
[15] Ritonga Tej, Tarigan U. Pengaruh Kepemimpinan Terhadap Kinerja Pegawai Pada Kantor Sub.Dolog Wil.IV Padangsidimpuan (Studi Pada Kantor Sub.Dolog Wil.Iv Padangsidimpuan). Jurnal Administrasi Publik. 2015 Jun;5(2015):79-93.

[16] Yuli Elisiana F, Administrasi Bisnis J, Ilmu Sosial Dan Ilmu Politik F, Diponegoro U, Susanta Msi Hn, Susanta Hn. [Jurnal Ilmu Administrasi Bisnis] 2016 The Effect Of Leadership, Work Motivation And Work Environment Of Employee Performance (Case Study Of Pt. Aneka Ilmu Semarang Section Printing).
[17] Shalahuddin A. Pengaruh Kepemimpinan Dan Lingkungan Kerja Terhadap Komitmen Organisasional Dan Kinerja Karyawan Pt. Sumber Djantin Di Kalimantan Barat. Jurnal Manajemen Teori Dan Terapan| Journal Of Theory And Applied Management. 2016 Sep 29;6(2).

[18] Djawa SK. Pengaruh Kepemimpinan Dan Lingkungan Kerja Terhadap Kinerja Pegawai Pada Sekretariat DPRD Kabupaten Banggai. Jurnal Ilmiah Manajemen Emor. 2017 Jan;1(2018). 